\title{
大量生産部品のリコールを防止するための極值統計による新しい品質管理法
}

\author{
村上 敬宜*1, 町田 尚 ${ }^{* 2}$, 宮川 進*3, 高城 壽雄 ${ }^{* 4}$
}

\section{A new quality control method based on statistics of extremes for preventing recalls for mass production products}

\author{
Yukitaka MURAKAMI $^{* 1}$, Hisashi MACHIDA ${ }^{* 2}$, Susumu MIYAKAWA ${ }^{* 3}$ and Toshio TAKAGI*4 \\ ${ }^{* 1}$ Emeritus professor, Kyushu University, 6-20-7 Miwadai, Higashi-ku, Fukuoka-shi, Fukuoka 811-0212, Japan \\ ${ }^{* 2}$ Graduate School of Engineering Management, Shibaura Institute of Technology, 3-9-14 Shibaura, Minato-ku, Tokyo 108-8548, Japan \\ ${ }^{*}$ Materials Engineering R\&D Division, DENSO CORPORATION, 1-1 Showa-machi, Kariya-shi, Aichi 448-8661, Japan \\ ${ }^{* 4}$ President, TAKAGI Co. Ltd., 2-4-1 Ishida Minami, Kokuraminami-ku, Kitakyushu-shi, Fukuoka 802-8540, Japan
}

Received: 20 May 2017; Revised: 19 July 2017; Accepted: 16 August 2017

\begin{abstract}
Recently, recalls for mass production products such as car components have been frequently reported even for the case that the rate of defects is only of the order of ppm or less. The objective of this paper is to propose the solution to avoid the recall problem of the order of ppm for mass production products. Even if the defect rate is of the order of ppm or less, most of remaining safe products have to be recalled and be replaced by new components. Such a recall causes a great cost deficit if the very rare defect is possibly related to fatal accident. However, it is very difficult by the conventional quality control methods to find the defects of the order of ppm or less at the stage of design and production. This paper proposes a new practical quality control method to avoid the defects of the order of ppm or less for mass production products based on the statistics of extremes which has been successfully applied to fatigue strength evaluation of defective materials. First, several examples of the quality control method to avoid the troubles mainly caused by failures and damages of components will be presented. Next, it will be shown that the same approach also can be applied to other problems such as the optimum control of operational parameters and the selection of optimum materials through the index based on the statistics of extremes. It will be also shown that the same method can be applied not only mass production components but also to avoid the troubles and failure accidents for large machine components of small number production. The stress-strength model approach will be reviewed from the viewpoint of the statistics of extremes.
\end{abstract}

Key words : Quality control, Statistics of extremes, Defects, Recalls, Fatigue, $\sqrt{\text { area }}$ max parameter model, Nonmetallic inclusions, Cast Al alloys, Bearing steels, Spring steels

1. 緒 言

近年，自動車産業における競争の激化により，同一プラットホームでの生産量が巨大化し，さらに部品・材料 の共通化が進み，かつてないほどの量が同じ設計基準で生産されるようになっている．また，過去のリコール

No.17-00231 [DOI:10.1299/transjsme.17-00231], J-STAGE Advance Publication date : 29 August, 2017

${ }^{* 1}$ 正員, 名誉員 (下811-0212 福岡県福岡市東区美和台 6-20-7)

*2 正員, フェロー, 芝浦工業大学大学院工学マネジメント研究科（†108-8548 東京都港区芝浦 3-9-14）（元 日本精工（株）

*3 正員, (株) デンソー，材料技術部（テ448-8661＼cjkstart愛知県刈谷市昭和町 1-1）

*4 (株) タカギ（广802-8540 福岡県北九州市小倉南区石田南 2-4-1）

E-mail of corresponding author: murakami.yukitaka.600@m.kyushu-u.ac.jp 
（NANER, 2017，消費者庁，2017)や人命にかかわる事故発生から，消費者の品質意識も高まり，ひとたび大き なリコールや事故を起こせば自動車会社も部品会社も企業存続の危機に直面する (事例は文献参照)。こうした 状況下でも自動車技術は進化し続け, ハイブリッド車, 電気自動車, 燃料電池車, 自動運転車へ変化し, さらに 軽量化，小型化の要求は強くなっている．また新幹線で代表される鉄道輸送や民間航空機のような大量旅客輸送 では絶対的な安全性, 信頼性が要求される.このような状況下で, 従来の品質保証方式を続けていけば, 必ずや 大きな問題に直面寸ることは明らかである。これらのリコール製品の不具合率は数 ppm あるいはそれ以下であ る.にもかかわらず，その部品が人身事故などの重大事故の原因としての可能性が否定できなければ，問題のな い残りの同じ部品もリコールの対象になり，巨額の損失を招くことになる.リコールは製造物責任法で認められ ているが，事故を起こした製品そのものは製造物責任法の対象になる. 我が国の産業界は歴史的に製品の品質管 理には特別の重点をおいており, 我が国の製品の品質の高さは世界的にも高く評価されている. しかしながら, 過度の高い品質保証は当然製品の高コスト化につながり, 競争力の低下を招く.したがって, 疲労強度などに関 する研究は単に S-N 曲線を求めることや組織の微視的観察に留まらず，それらの成果を産業界の実践的問題の 解決にまでつなげることが期待される.

本論文で取り上げる課題は大量生産品の数 ppm オーダの不具合が原因となって, 残りの大部分の製品のリコ ールを余儀なくされる問題をいかに解決するかということである. 従来の代表的品質管理法としては，これまで よく知られた標準偏差を指標とする方法やタグチメソッド（田口, 1988), $\mathrm{DG}^{3}$ 法（吉村, 2002, 2011）などが知ら れている. 自動車部品などでは当然新たな開発品の耐久試験を行い, 試験の範囲内では不具合が起こらないこと を確認するのであるが, 従来の方法では数 ppm オーダの極少数の不具合を確実に見出すことは困難である. 従 来の方法では, 設計段階では, 極めてまれに起こる疲労破壊などは把握しにくく, 市場で起こる不具合の原因を 定量的に把握することなく, 最終的な品質保証を根拠が曖昧な安全率で補うという発想が根底にあるからであ る，そのような方法で不具合が起こらなければ，一応その製品の設計は成功とみなされるが，その製品で採用し た安全率の裏に可能性のある原因が隠され，同じ設計法を次の製品に適用したときにその原因が不具合の原因と して現れることがある．同じ問題は，大量生産品に限らず，大型少量生産品の開発などでも経験される.

本論文では，極值統計法（Gumbel,1958，高橋，志村, 2016）を大量生産部品の品質管理に適用し，市場で起こ る数 ppm 程度の不具合発生を製品開発の初期段階から防止する実践的手法を提案する. 多くの不具合は部品の 疲労破壊などが原因になっている，村上らは，これまで $\sqrt{\text { area }}$ パラメータモデル (Murakami and Endo, 1994, 村 上, 1993, Murakami, 2002）と極值統計法を組み合わせて微小欠陥を有する材料の疲労強度のばらつきの下限值を 予測する方法を提案してきた. 本論文では, 部品の強度の視点から見た不具合を防止する品質管理の方法を中心 に説明するが，基本的には他の種々の使用形態の動作パラメータから見た機能評価や材料選択の指標にも利用で きることを例示しながら説明する．また，ここで提案する品質管理手法は，大量生産製品だけに限らず，原理的 に少量生産の大型機械の不具合または事故防止にも応用可能なものである.

\section{2. 極値統計法とそれに基づく極値の予測の意味について}

極值統計は歴史的には海洋の巨大波や河川の洪水などの予測に用いられてきた. 海洋の巨大波の予測は船舶や 海洋構造物が受ける荷重予測と強度設計に生かされる. 河川の洪水の予測は災害を防止する堤防や橋の設計に必 要である.

図 1 は, ミシシッピー川の 52 年間 $(N=52)$ の洪水の極值統計データを示している(Gumbel, 1958). 川の水量は毎

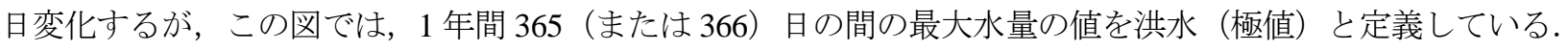
縦軸 $y$ は基準化変数(Reduced variate) と呼ばれる量で, 同じ縦軸に再帰期間 $T$ (Return period)の目盛りも示してい る. 横軸は洪水を示寸水量である. 縦軸の基準化変数 $y$ は直感的には捉えがたい量であるが，二重対数になって いることに注目すれば，記録的な大洪水の発生は多頻度で起こるのではなく長期間を要することが理解できる. 再帰期間 $T$ の目盛りは，どれほどの大洪水が発生するにはどれぐらいの長期間がかかるかを示している. 再帰 期間 $T$ と同じ方向にとった累積確率 $F($ Cumulative frequency または単に確率 Probability）は

$$
F=n /(N+1) \times 100(\%)
$$


で表される.

ここで， $n$ は $N$ 個の中で，極值を小さい值から大きい值に順に並べたときの $n$ 番目の極值の番号を意味する.

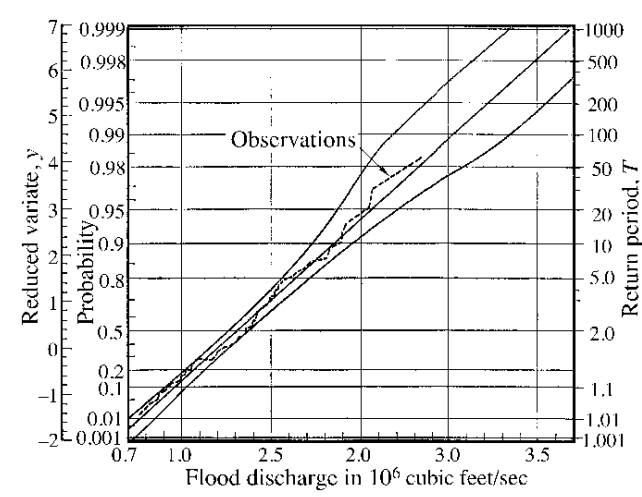

Fig. 1 Statistics of extremes analysis of 52 years flood data of Mississippi river (Modified from (Gumbel, 1958)).

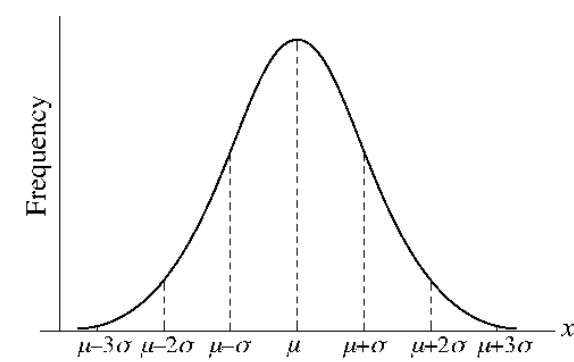

Fig.2 Typical yearly frequency of water level.

寸なわち，極值統計データは，これまでに経験した最大の洪水を基に堤防や橋の建設をするのではなく，将来 に亘って起こりうる大洪水を考慮に入れるために有用なのである.これを大量生産部品に置き換えて考えれば, 10 個や 20 個の部品の耐久試験を行い, その平均值や最弱值を基に従来どおりの設計を行っても数十万個, 数百 万個に達する部品の品質を保証することはできないことを意味している. 従来の品質管理手法では, 製品の不具 合の確率には注目寸るが，不具合の原因となる欠陥などを同定し，それを定量的に把握する方法を見出していな い.ここに最近のリコール多発の根本原因があるのである.

図 1 のような極值統計解析は母集団が正規分布や指数分布のように分布の裾野（tail）が指数関数分布を有し ている場合に適用可能である. 寸なわち，図１の場合，母集団となるミシシッピー川の水量の分布は，縦軸に日 数, 横軸に水量をとったとき, 図 2 のように正規分布になることを仮定している. 河川の洪水の場合には, 地 球温暖化の影響で母集団の分布に変化が起こる可能性もあるが，少なくとも過去数十年のデータを拠所にしな がら，母集団の変化に注目することになるであろう。自動車部品に代表される機械部品も部品の耐久試験で得ら れる強度などの量は当然ばらつきを示し，そのばらつきは正規分布と仮定されることが多いが，不具合の元々の 原因となる欠陥や材料中の非金属介在物などは指数分布に近いことに注意しておかねばならない.

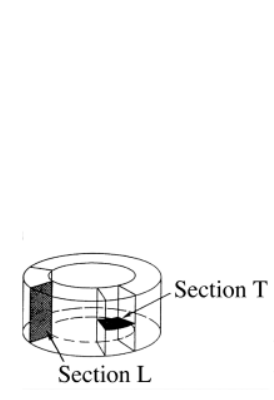

(a) Definition of inspection planes

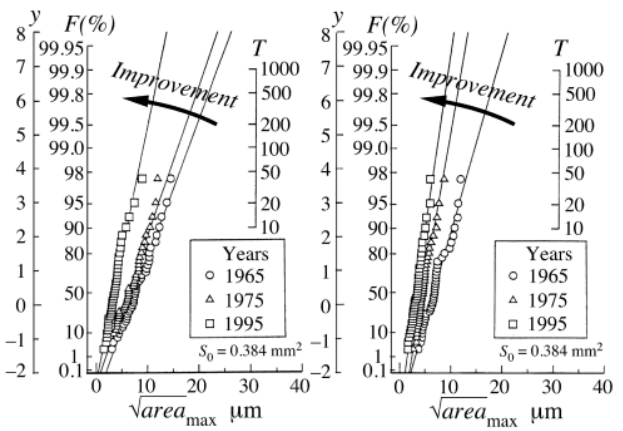

(b) Section $\mathrm{T}$

(c) Section L

Fig. 3 Variation of cleanliness in bearing steels since 1965. Inclusion rating was made based on the statistics of extremes analysis. (Modified from (Y. Murakami, 2002)).

図 3 は，1960 年代から 1990 年代にかけて製造された軸受の品質を介在物の極值統計の観点から評価したもの である．軸受の縦断面と横断面について，基準面積 $S_{0}=0.384 \mathrm{~mm}^{2}$ 当たりに観察される最大の介在物寸法を顕微鏡 観察で観察し，極值統計プロットしたものである．時代とともに軸受鋼の清浄度が改善されている様子が理解で 
きる.この方法は，時代の差だけでなくむしろ製鋼メーカの実力差の評価に有効である.この方法（村上， 1993, Murakami, 2002）は 2002 年に ASTM Standard（ASTM, 2002）として採用されている. 我が国の介在物評価 法は 1955 年に JIS 点算法が制定されたが，もはや有效性を失ったまま放置されている. 図 3 の例は, 狭い面積 の顕微鏡観察を基にしたものであるが，最近は，超音波疲労試験（Furuya et al., 2003）や水素チャージを利用し た方法（Fujita and Murakami, 2013）が提案されている. これらの方法は 1 本の試験片や 1 つの部品の中の最大介 在物を代表值として取り出すので信頼性が高い.

\section{3. リコールを防止するための方法}

\section{$3 \cdot 1$ 不具合要因の発見と極值統計解析の方法}

不具合要因を見出寸ためには対象部品に過大負荷を与えて壞してみることが重要な糸口になる．先に述べたよ うに，10あるいは 20 個程度の対象部品について設計荷重での耐久テストを行って安全性（不具合が発生しない こと）を確認する手法では市場での数 ppm オーダの不具合を発見することはできない. 過大負荷によって壊す ことによって, すなわち強制的に不具合を発生させることによって, 数 ppmオーダの不具合の原因を見出し, さらに原因の大きさ（すなわち極值）を定量的に評価することができるのである.

この手法の手順は次のように纒めることができる，ただし，手順を実行する場合のサンプル数などは個々の場 合によって適切に選ぶ必要がある.

(1) $N$ 個（例えば， $N=10 ~ 40 ） の$ 当該部品を壊す試験を行う。

図 4 は, 疲労試験の破壞面に観察された非金属介在物の例を示す。このような非金属介在物はしばしば機械部 品の破壊起点になる. ばね, 軸受, 歯車, 車軸などはこの種の問題を抱えている. 1 つの部品や試験片に含まれ 万介在物の数は膨大で, 寸法は $1 \mu \mathrm{m}$ 程度の極めて微小なものから図 4 に示寸ような比較的大きなものもあり, 母集団の分布はほぼ指数分布になる．部品ごとに最大の介在物（極值）の寸法が異なるので，同じ荷重または応 力を負荷しても部品または試験片の疲労寿命が大きくばらつく.

(2) 試験によって破壊した箇所に観察される破壊起点の欠陥などの寸法を $d_{\text {max }, i}$ とする. すなわち，破壊の原因に ならない微小な欠陥は無数にあるが，破壊試験でこれらの中の最大のもの（代表值または極值という）を取り出 寸ことになる．これによって $N$ 個の代表值（極值）が得られる．例えば，図 4 のような介在物がその試験片の代 表值である. 非金属介在物形状は一般に必ずしも円形とは限らないので, 疲労や破壊の分野では, き裂の応力拡 大係数の最大值と相関をもつ代表寸法として, 介在物の面積 area,$i_{i}$ を測定し, 長さの次元を持つその平方根 $\sqrt{\text { area }}, i$ を採用する(Murakami and Endo, 1994, 村上, 1993, Murakami, 2002). 寸なわち， $d_{\max , i}=\sqrt{\text { area }}, i$ である.

(3) $d_{\max , i}(i=1-N)$ を小さい值から大きい值まで並べ直し, 番号を小さいものから順に $d_{\max , n}(n=1 \sim N)$ のうにつけ

る. 寸なわち, $d_{\max , 1}$ が $N$ 個の代表值の中で最小值で， $d_{\max , N}$ が最大值である.

(4) $d_{\max , n}$ を図 5 のように, 極值統計グラフにプロットする．横軸の值は $d_{\max , n}$ で縦軸の值は $n /(N+1) \times 100 \%$ あ る.プロットしたデータが極值統計グラフ上で直線を示せば, データは極值統計に従うと考えてよい.

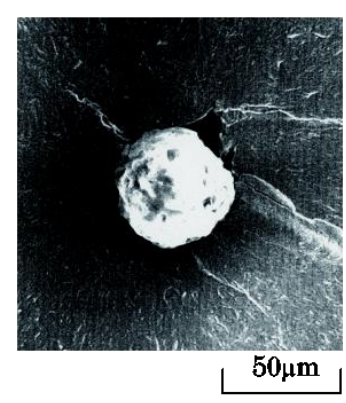

Fig. 4 Inclusion observed at fracture origin (Murakami et al., 2000a).

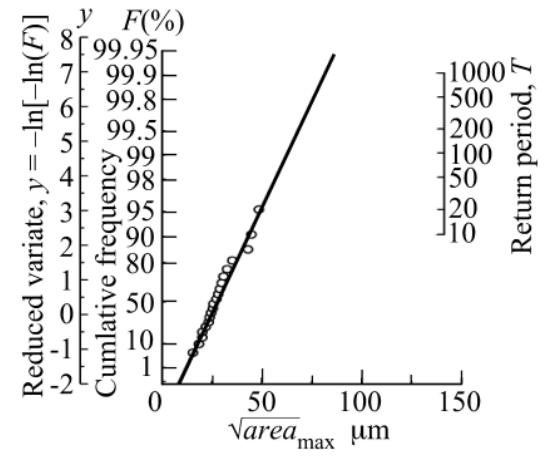

Fig. 5 Statistics of extremes of inclusions. 
(5) $N$ 個以上の試験片または部品に含まれることが予想される $d_{\max }(=\sqrt{\text { area }}$ max $)$ を求めるには，その総数を $N_{\mathrm{T}}$ とす ると, 再帰期間 $T=N_{\mathrm{T}}$ の目盛りに相当する $d_{\max }(=\sqrt{\text { area }}$ max $)$ を求めればよい. 試験片でデータ取得し, 試験片 より大型の部材中の最大值を求めるには, 試験片の体積を $V_{0}$ (基準体積, Standard volume), 生産される部品の総 体積を $V_{\mathrm{T}}$ とすると， $T=V_{\mathrm{T}} / V_{0}$ の目盛りに相当する $d_{\max }(=\sqrt{\text { area }} \max )$ を求めればよい. なお，ここで体積とは高い 応力（定義は付録参照）が作用し，破壊起点となることが予想される部位の体積（危険体積）であり，部品の全 体積ではない，総体積とは，1部品の危険部位の体積に生産部品数を乗じた体積である.

\section{$3 \cdot 2$ 不具合要因の極值統計データと設計への反映}

前節の手順によって不具合を起こすことが予想される原因の極值統計データが得られれば，種々の方法でそれ を設計に生かすことができる，その具体例を以下に示す．

図 5 は次の 2 つ重要な情報を与えてくれる.

（1）図 5 の直線を外捜寸ることにより，試験を行った $N$ 個より多数の部品に含まれることが予想される欠 陥の最大寸法 $d_{\max }$ を予想することができる．例えば，市場に投入する部品または製品の数を 10 万個と仮定する と, 試験した部品の数に比較する值として定義される再帰期間 $T$ を $T=10^{5}$ で表す縦軸の位置まで直線を外捜し, その位置での横軸の值 $d_{\max , T=10^{5}}$ を読みとる. 図 5 の直線のデータが試験片によって得られたものであれば，実際 の部品に応用寸るには, 前節の（5）で述べたように試験片の体積と部品の総体積を基にした再帰期間 $T$ を用 いればよい。

（2）別の方法または別の材料で同じ部品を製造し，同様な試験を行った結果を図 5 に合わせてプロットする と前回の品質との差が一目瞭然となる. 前回の試験の結果を示す直線を A とし, 別の直線を B とすると, B が A より左側に位置し，しかも傾きが A より急であれば大量生産での品質は A より B が良いということになる. また，B が A より左側に位置しておれば，相対的に B の品質が良いといえるが，量が多くなれば，直線の傾き を考慮に入れなければならない。この性質は適切な材料選択や部品供給メーカに対する技術評価にも利用でき る.このような視点で図 3 を見ると, 軸受鋼の清浄度が年代によってどのように改善されたか一目瞭然となる.

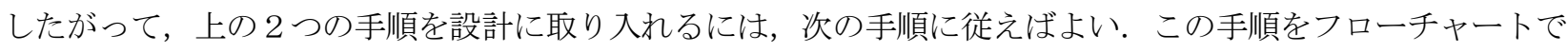
表現することもできるが，内容を理解しないままマニュアル的にフローチャートに従えば，問題点を見過ごす恐 れもあるので，あえて文章で説明する.

(a)

（a-1）まず（1）の手順で生産量に相当する最大の欠陥寸法を推定する．その寸法を考慮して付録に示す強度計 算などを行う。その計算によって品質が保証できれば一応合格である.

(a-2) しかし, 不具合の可能性が見出されれば,（2）の手順による改善を行わなければならない. すなわち, 先 ず形状・寸法または製造方法の変更を試みることが選択肢の 1 つになる，ただし，この段階では，安全率の設定 の検討は行わない，曖昧な安全率の設定はあるべき技術の追求を妨げる．環境因子などを考慮した安全率は，こ の手順での設計を終了した後に検討する.

(b) 次の選択肢は材料の変更である. 材料の変更は必ずしも別の種類の材料へ変更することを意味しない. 例え ば，軸受鋼 SUJ2(SAE52100)は名前が同じでも，介在物寸法の極值統計データは図 3 のようになり，世界の製鋼 企業の実力には差があることが知られている. ばねのように多量生産部品では, ばね鋼について同様な問題が知 られている (斉藤, 伊藤, 1985, 村上他, 1990, 村上他, 1991)。このような例では, 清浄度の高い材料への変更が 1 つの有効な解決策となる. 材料を異なる種類のものに変更する場合には, 前節の手順に従って新たな極值デー 夕を取得することになる，熱処理を変更すれば，基地組織の強度は向上寸るかもしれないが，介在物の寸法は変 わらないことに注意しなければならない，また，基地組織の静的強度が高くなる（硬く）なると，基地組織その ものの疲労強度は上昇寸るが，疲労強度は小寸法の介在物にも敏感になることにも留意しなければならない。

\section{$3 \cdot 3$ 極值統計法を利用した設計と品質保証の事例 事例 1 鋳造アルミ合金部品の疲労強度設計}

図 6(a), (b) は, トラックのロッカーアーム用A1 合金の鋳造欠陥を示している (小林, 1995)。大寸法の鋳造欠陥 は疲労強度に有害であり，許容応力を高く設定することは困難になる．欠陥寸法を小さくする鋳造方法で品質の よい部品を製造することが望ましいがコストの増大につながる. また，少量の検査で欠陥寸法が小さくても，大 
量生産の中にはばらつきによって大寸法の欠陥を含むものが出てくる可能性もある.このような場合，どのよう な鋳造方法なら許されるかを判断する場合に，極值統計が有用なのである.

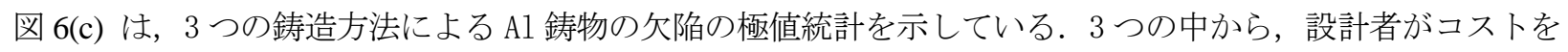
考慮して，どれを選択寸るかということになるが，どれほどの部品数を生産するか，その中で最大寸法の欠皕は どれほどかを定量的に判断できるから, 従来の曖昧な安全率に基づく設計より, はるかに信頼性が高い.

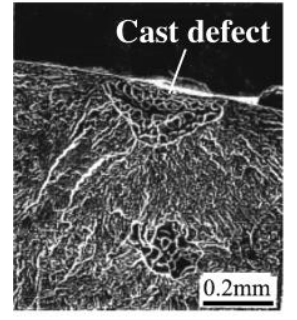

(a) Cast defect at fracture origin

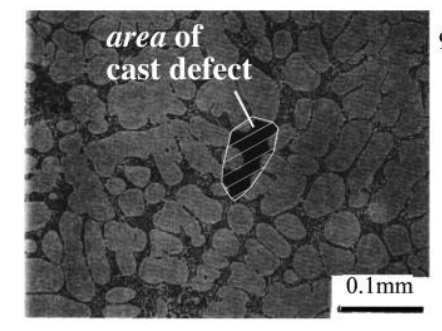

(b) Definition for area of cast defect

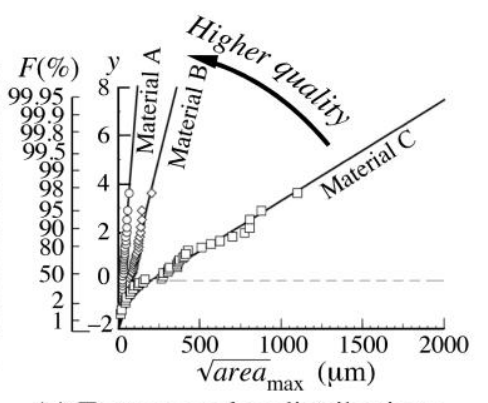

(c) Extreme value distributions of cast defect size

Fig. 6 Cast defects in $\mathrm{Al}$ alloy and analysis of cast grades based on the statistic of extremes. (Modified from (Kobayashi, 1995)).

\section{事例 2 エアコン用スクロールコンプレッサー用部品開発への適用}

これまでアルミニウム合金ダイカスト材料は低い負荷の構造部品として使われていた．地球環境保護の観点か ら自動車部品の高性能化や小型・軽量化が求められている。このような状況で, 高い負荷に耐えるエアコン用ス クロールコンプレッサー用部品開発が必要になった。これまでは製品を市場に出すまでに耐久試験で疲労破壞す るたびに工程改善が必要であった。耐久試験で疲労破壊が頻発すれば工程改善を繰返さなくてはならず開発期間 の長期化をまねく，そこで，次期型製品を限られた期間で開発するにあたって，極值統計法による新しい品質保 証法の提案を行った. ダイカスト法は大量生産面，コスト面および複雑形状に対応可能であるので，各種軽量化 材料の中からアルミニウム合金ダイカストを選定した（山田他, 2002）.

材料中の鋳造欠陥評価に極值統計法を適用し，疲労強度評価に $\sqrt{\text { area }}$ パラメータモデル（付録参照）を用いた (図 7(a), (b)). 開発過程を以下に示す.

1. 許容欠陥寸法に注目した工程開発.

2. 切削加工の影響 (残留応力), 熱処理の影響（硬さ), 表面処理の影響等の評価.

このような開発を成功させるには，材料分野，処理分野，加工分野（ダイカスト部門，熱処理含）および設計分 野(耐久試験，この場合 F EM解析も対応)が一体となった活動が必要である．なお，疲労強度評価結果を $\sqrt{\text { area }}$ パラメータモデルで図化した図 7(c)は材料開発の指針を示すことに役立つものと思われる． 鋳造欠陥に対して 極值統計を適用したこの設計方法はその後の他製品の次期型製品開発にも受け継がれている.

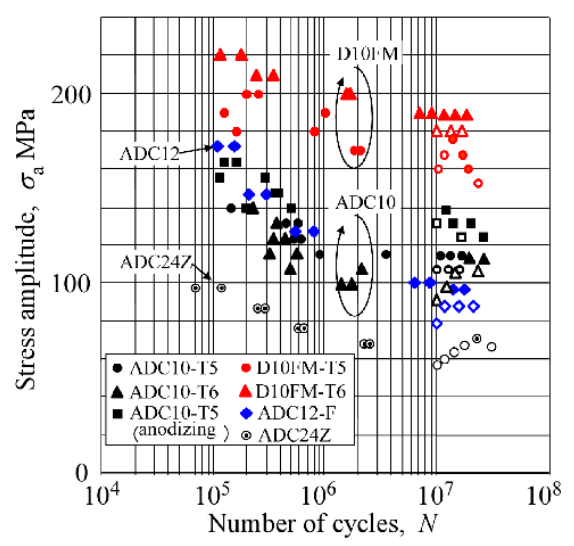

(a) Fatigue properties of cast materials

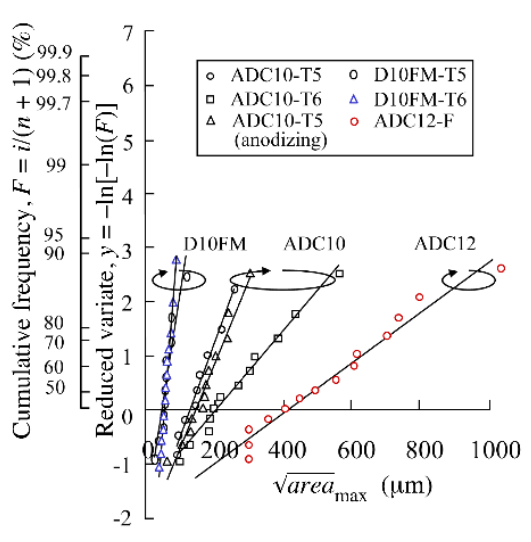

(b) Statistics of extremes of cast defects

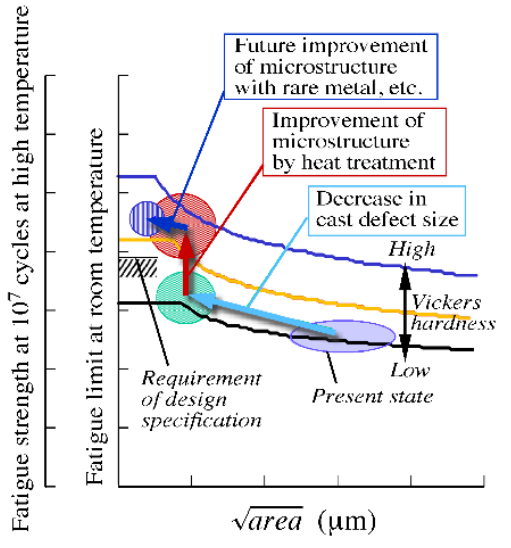

(c) Direction of improvement of fatigue properties

Fig. 7 Development of high fatigue strength Al alloys for car compressor based on fatigue tests, statistics of extremes analysis of cast defects and the $\sqrt{\text { area }}$ parameter model. 


\section{事例 3 Half Toroidal CVT の超長寿命疲労強度設計}

図 8 に示す Half Toroidal CVT は車両用や航空機用無段変速装置として開発された（Machida and Abe, 1996, Machida, 2005) . 歯車による変速によらないので，極めてスムースな変速が可能である. このCVT は世界で数十 年にわたり開発が進められていたが，開発初期から予想された困難は潤滑特性と摩擦特性という相反する両方の 機能を発揮する潤滑油の開発であった。この困難を克服して，開発は達成されたと思われた。しかし，性能確認 のために行った耐久試験において新たな問題が発生した. 問題はオイルだけでなく, 部品の疲労破壊にあった. 大さな摩擦力を発生させるためには大きな押し付け力をかける必要があり, その押し付け力により部品内部には 大きな応力が発生して非金属介在物から疲労破壊を招いていた.さらに自動車のエンジン出力は数十年の間にど んどん大きくなった，そのエンジンに見合うだけの応力設計ができていなかった. この材料の問題を試験片の引 張圧縮疲労試験で調査したところ, 試験片でも疲労破壊の起点はすべて非金属介在物であった. さらに，疲労試 験の結果は疲労限度を示さない超長寿命疲労現象（Murakami et al., 2000a, 2000b）を示すものであった.すなわ ち，疲労限度を求め，それに安全率を考慮した通常の疲労限度設計は通用しないことが明らかになった。この CVT に関する疲労限度を示さない超長寿命疲労現象は水素を含むガス中での熱処理過程で介在物にトラップさ れた水素が関与し, 介在物の寸法が大きいほど寿命が短いことが明らかにされたので, 設計には最大介在物寸法 と CVT の運転保証繰返し数（疲労寿命）との関係が必要になった. 介在物寸法と必要な運転保証繰返し数（疲 労寿命）から設計応力（許容応力に相当）を決定するために $\sqrt{\text { area }}$ パラメータモデル（Murakami, 2002, Murakami and Endo, 1994）を適用した（詳細は付録参照).

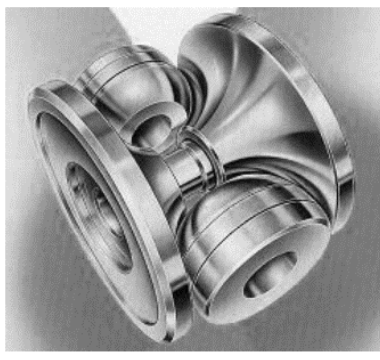

Fig. 8 Half Toroidal CVT.
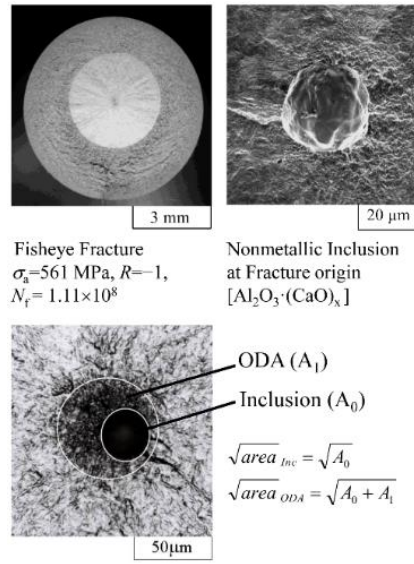
.

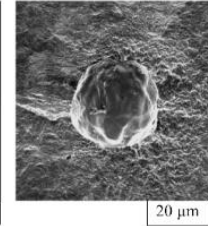
$N_{\mathrm{f}}=1.44 \times 10^{5} \quad \begin{array}{ll}\sigma=883 \mathrm{MPa}, \\ N_{\mathrm{r}}=3.82 \times 10^{5}\end{array}$ $\begin{array}{ll}N_{\mathrm{f}}=1.44 \times 10^{5} & N_{\mathrm{f}}=3.82 \times 10^{5} \\ \sqrt{\text { area }}=45 \mu \mathrm{m} & \sqrt{\text { area }}=33 \mu \mathrm{m}\end{array}$

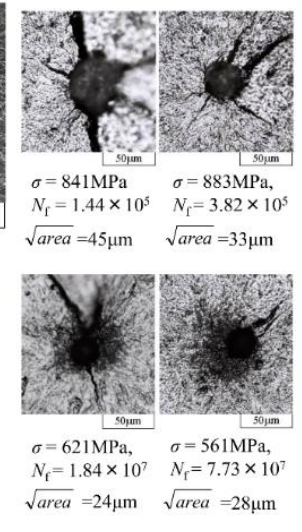

Fig. 9 Fatigue fracture origin and ODA (Optically Dark Area).
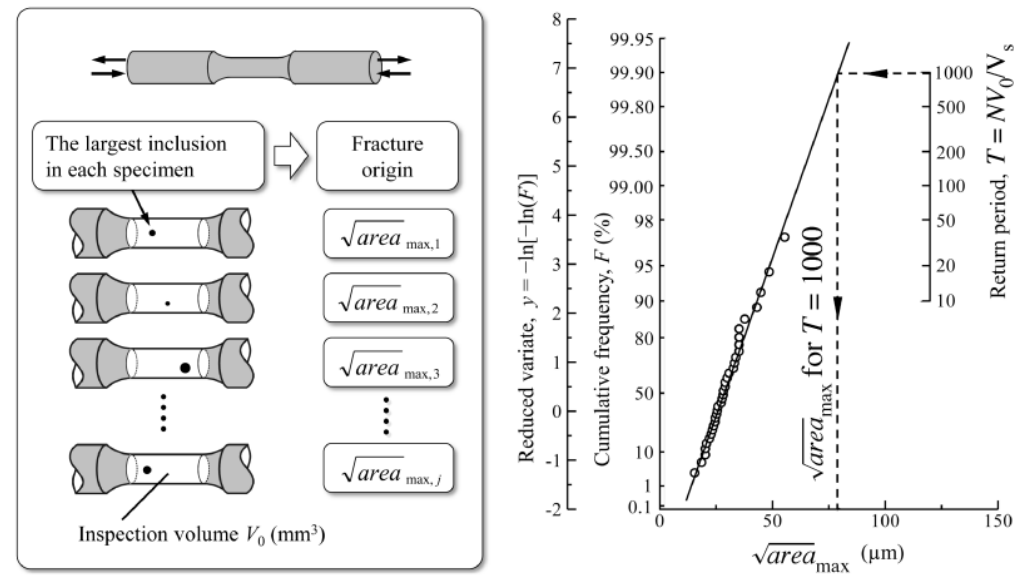

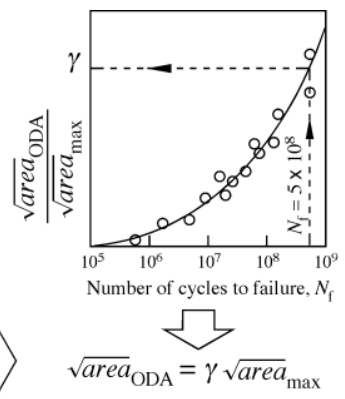

(b) Growth of ODA with fatigue life and prediction of $\sqrt{\text { area }}$ ODA

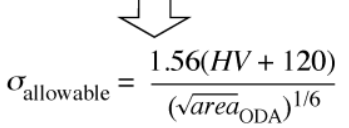

(c) Prediction of allowable stress

(a) Inclusion rating by fatigue test and statistics of extremes

Fig. 10 Very high cycle fatigue design concept for Half Toroidal CVT based on inclusion rating, statistics of extremes and fatigue crack growth curve of hydrogen influenced area around inclusion. 
先ず調査すべきことは Half Toroidal CVT に使用される材料(SCM435)に含まれる介在物の寸法の極值統計デー タである. 例えば, 図 5 のように 10〜40 本程度の試験片について引張り圧縮疲労試験を行い, 破断面に観察さ れた介在物寸法の極值統計データを得る．先に述べたように，介在物周辺には図 9 のような水素の関与によって 疲労き裂成長が助長される領域 ODA（Optically Dark Area）が観察される（Murakami et al., 2000a, 2000b, Roiko and Murakami, 2012). ODA 寸法が作用応力のもとで水素の助長無しでも成長可能な疲労き裂進展下限界值 $\Delta K_{\mathrm{th}}$ を満たす寸法にまで達すると, き裂は水素の関与無しに進展を開始する（Murakami et al., 2000a, 2000b, Yamashita

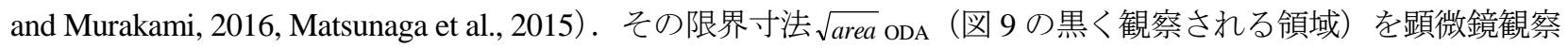
で測定すると，元の介在物寸法 $\sqrt{\text { area }}$ と $\sqrt{\text { area }}$ ODA と疲労寿命との間にほぼ 1 対 1 の関係があることが明らかにな

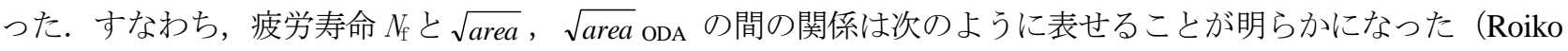
and Murakami, 2012, Yamashita and Murakami, 2016).

$$
N_{\mathrm{f}}=f(\sqrt{\text { area }} \text { ODA } / \sqrt{\text { area }})
$$

この関係を図示すれば，図 10(b) のようになる。この場合には水素が影響することで疲労限度は存在しないの で，通常の疲労限度設計ではなく，超長寿命疲労現象を考慮した寿命設計を行わなければならない。このような 新たに発見された現象を知らずに製造すると, リコールを避けることはできない. 仮に, 市場での想定寿命 $N_{\mathrm{f}}$ を $N_{\mathrm{f}}=5 \times 10^{8}$ に設定すると，図 10(a) の極值統計データを利用する設計手順は次のようになる.

1．極值統計データを求めるため行った疲労試験片の試験部の体積 $V_{\mathrm{s}}$ を計算する.

2 . 介在物が疲労破壊起点となる可能性がある部品 1 個中の危険体積 $V_{0}$ を計算する.

3 . 部品の生産数 $N$ を決定する.

4. 再帰期間 $T$ (Return period)を決定する. $T=N V_{0} / V_{\mathrm{s}}$

5. 極值統計グラフ (図 10(a)）の再帰期間 $T$ に相当する予想最大介在物寸法 $\sqrt{\text { area }}$ max を推定する.

6. 予想最大介在物の寸法が $\sqrt{\text { area }}$ max から ODA を加えた寸法 $\sqrt{\text { area ODA }}$ に成長寸る程度 $\gamma$ $(\gamma=\sqrt{\text { area }}$ ODA $/ \sqrt{\text { area }}$ max $)$ を設定寿命 $N_{\mathrm{f}}=5 \times 108$ から推定する（図 10(b)).

7. $\sqrt{\text { area }} \mathrm{ODA}$ を $\sqrt{\text { area }}$ パラメータモデルの疲労強度予測式（付録参照）に代入し, 許容応力を決定する.

以上説明したように，軸受鋼のような熱処理した高強度鋼で非金属介在物を起点とした疲労破壊の可能性があ る場合には，通常の疲労限度設計ではなく使用期間中に部品に繰り返される応力サイクルを考慮した超長疲労寿 命設計を行うことがリコールの原因となる不具合を避ける方法になる．この方法は，曖昧な安全率を設定するの ではなく, 部品の生産数に対応した強度の下限值を許容応力として設定する. このように Half Toroidal CVT で は，新しい品質保証の理念を導入することでこれまで一件の不具合も発生させていない．

ここで紹介した事例は大量生産部品を対象にしたものであるが，同じ手法は舶用ジーゼルエンジンのクランク シャフト，歯車，タービンローター，製鉄用圧延ロールなどの大型機械製品にも適用可能である.この場合は, 製品の生産数としては少ないが，破損の可能性のある部位の体積は小型の大量生産品の総体積にも匹敵するの で, 小寸法の試験片から得られた介在物などの欠陥に関する極值データにおける再帰期間 $T$ は小寸法の大量生 産部品と同様に極めて大きくなる．この方向の品質管理はいくつかの企業においてすでに実績が得られつつあ る. 少量大型製品の問題は, 大量生産数の中の $\mathrm{ppm}$ 程度の破壊または不具合による全製品のリコールではな く, 一つの久陥を起点とする大型製品の壞滅的破壞または損傷である.

\section{事例 4 リコールとなったエンジンバルブスプリング}

自動車エンジンの弁ばね（Valve spring）は自動車部品の中でも部品数が多い要素である. 弁ばねの損傷はクル マの心臟ともいうべきエンジンの動作に直接影響寸るので，重大な事故につながる可能性が高い，弁ばねの耐久 性については, 当然ばねの要素試験のほかエンジンの耐久試験の中でも確認されるはずである. しかし，それで もリコールに至る損傷が起こることがある．弁ばねの材料には硬さの高い高強度鋼が使用される. ばねの疲労破 壊ではしばしば非金属介在物が破壊起点になる（村上, 1993, Murakami, 2002, 斉藤, 伊藤, 1985)。そのため, 介 在物の寸法を小さくするたゆまない努力がなされてきた（斉藤, 伊藤, 1985). それでも, 生産部品個数が 
$10^{5} \sim 10^{6}$ のオーダあるいはそれ以上の数になれば，通常の品質管理法では $1 \mathrm{ppm}$ オーダの不具合の発見は困難で ある.

図 11(a)は，そのようなリコールの対象になった弁ばねを示す．図 11(b), (c)は，このばねに観察された非金属 介在物である。非金属介在物の存在を確かめるために，同種の弁ばねに一旦焼き鈍しを施し，直線に伸ばした 後，焼入れを行い硬さを高めた。次に，それに水素チャージを施し，引張り試験を行ったところ破壊面に介在物 が現れた（方法については Fujita and Murakami, 2013 を参照）。このばねに限ると介在物は寸法が小さく，通常の 設計で想定された使用条件では破壊の起点になる可能性はないと考えられる.

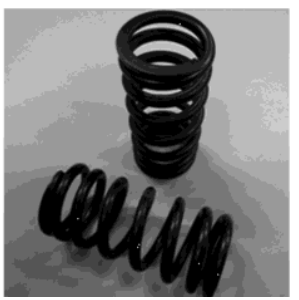

(a)

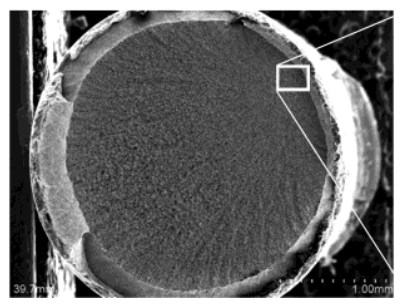

(b)

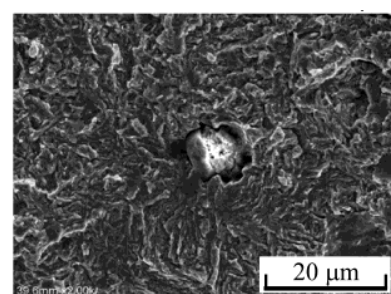

(c)

Fig. 11 (a) Valve spring. (b) Tensile fracture by hydrogen embrittlement. (c) Nonmetallic inclusion at fracture origin of (b).

介在物寸法の統計的分布特性を考慮すると，リコールの原因となった弁ばねには図 11(c)よりかなり大寸法の 非金属介在物が存在していたことが推定される．そのような大寸法の介在物は設計時には想定されず，耐久試験 でも見出すことは困難である．市場では $10^{5} \sim 10^{6}$ のオーダあるいはそれ以上の個数のばねの耐久試験を実施して いるのと等価なのである，それでは，このようなリコールを未然に防止するにはどうしたらよいであろうか?そ れには，次のような方法が考えられる．ばねに加工寸る前の鋼線を焼入れし，硬さを高め，次に水素チャージを 施した試験片を 50 100 本程度準備する．本数が多いほど予測の信頼性が高いことはもちろんである．これらの 試験片を引張り試験し，破壊面に現れた非金属介在物の寸法を測定し，極值統計グラフにプロットする．市場に 投入するクルマの生産台数から予想される弁ばねの個数 $N_{\mathrm{T}}$ を再帰期間 $T=N_{\mathrm{T}}$ として, 外捜によって, 市場での

最大介在物寸法を推定する. 事例 3 と同様な手法で弁ばねのビッカース硬さ $H V$ と最大介在物寸法を基に疲労限 度を推定する．ただし，ばねに作用する応力はねじりであるから疲労限度推定にはそのことを考慮しなければな らない. また, 介在物を起点とする疲労破壊では, 介在物がトラップする水素の影響で疲労限度が消滅する現象 があるので，市場での繰返し数に応じて有効な欠陥寸法を実際より大きめに評価しなければならない（事例 3 と 付録参照).

この種の問題は設計技術者だけの努力で解決できるものではない. 仮に，クルマメーカが数社の製鋼メーカに 新たなばね材料の開発を要請したとしよう。このとき， 1 社の他は問題点を挙げて困難を指摘した場合に，受注 に成功した 1 社が指摘された問題点を真に解決するかどうかに注目しなければならない. ばねメーカについても 同様である.ばねを 100 個耐久試験したとする，その場合に 1 個だけ異状に強度が低いデータが出たとしよう. これを異常值として捨て去り, クルマメーカに強度保証をしても, 開発段階のエンジンの耐久試験では, この異 常值（極值）は発現しない可能性が高い。しかし，市場ではほぼ確実に不具合となって現れるのである。このよ うな問題を避けるためには，製鋼，ばね製造，設計に関わる技術者間での情報交換による現象の共有と極值統計 データに基づいた製鋼プロセス変更へのフィードバックが必要である.

\section{事例 5 機能パラメータ（作動荷重など）の極值統計評価による品質管理（疲労破壊以外の対象への適用）}

1 種類の部品の品質管理では通常正規分布を示寸ばらつきに注目寸るが，複数の部品を組みつけて 1 つの製品 にする場合には構成部品の個々のばらつきが正規分布であっても全体としての機能のばらつきが正規分布になる とは限らない，このような場合には，タグチメソッドはロバストな設計として有効である。しかし，複数の構成 部品からなる製品の ppm 以下の不具合を防止するにはどうしたらよいであろうか. このような事例として，一 般家庭で使用されている蛇口を取り上げる (淺野間他, 2017)。蛇口の主なトラブル事例としては「水漏孔」や

「レバーハンドル操作が重い」現象がある. これらトラブルの主要因子として, 図 12 の概略図に示すセラミッ クディスクの表面性状およびセラミックディスク間の面圧の大きさ $N$ に注目した. 
セラミックディスク間の面圧 $P$ が低い場合は「水漏れ」が生じ，高い場合は「レバーハンドル操作が重い」 など操作力 $F$ の増大につながるので, 面圧 $P$ の適正な管理が必要である. 面圧 $P$ は各部品の寸法および物性に より決まるので，複数の部品が組みあがったバルブ部品での状態では，その值にばらつきが生じることは避けら れない，したがって，量産時において，面圧のばらつきを把握し，生産量に対応した最大值及び最小值を管理す ることが極めて少数の不具合製品に起因する全製品のリコールを回避するために必要である.

まず，一定押し込み変位に対する面圧のばらつきを調査したところ，ばらつきは正規分布ではなく，極值分布

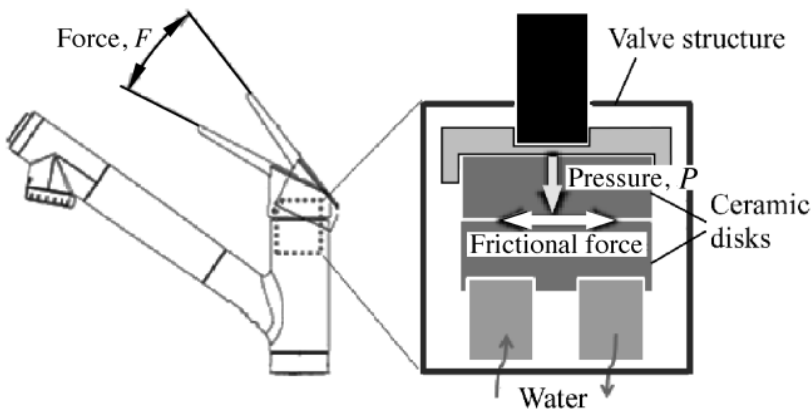

Fig. 12 Structural model of faucet system.

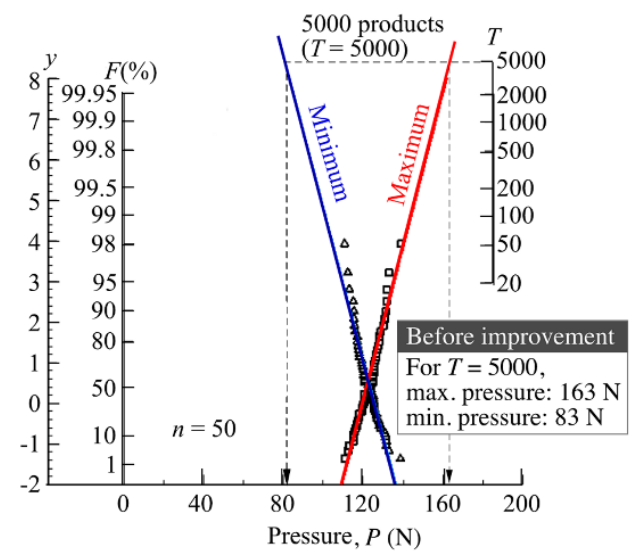

Fig. 13 Statistical property of pressure $P$ in 50 tests.

に近いゆがんだ分布であることがわかったそそこで，開発過程において極值統計法を面圧の管理に適用するこ とで大量生産品の品質管理を実施した.

まず，同じ生産ラインで製造したバルブ部品を 50 個抜き取り，作動テストによる面圧を極值統計グラフにプ ロットした．その結果を図 13 に示寸．データの直線性からこの製品のばらつきは極值統計に従うことが明らか になった．生産量 5000 個（再帰期間 $T=5000 ） に$ 対寸る面圧の各推定值が過去に不具合を起こした経験から得ら れた管理上下限值内であることを確認した。

レバーの操作感をさらに改善するためには，水漏れが生じないことを担保しつつ面圧を下げることが求められ る. そこで，さらに一部の部品の成形条件を見直し，極值分布を求めた．成形条件を見直し後，同様に 50 個抜 き取り, 面圧の極值統計分布を求めた. その結果を図 14(a) と図 14(b)に示す. 最大面圧の推定值が成形条件見直 し前後で低くなったことが確認できる.

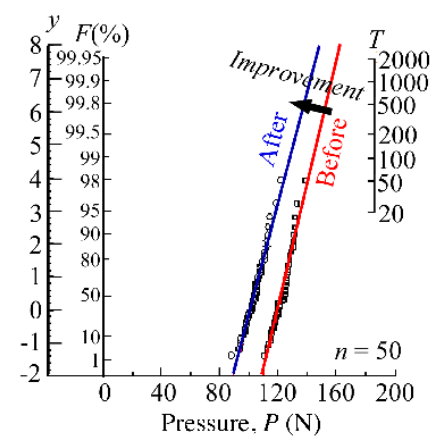

(a) Maximum pressure

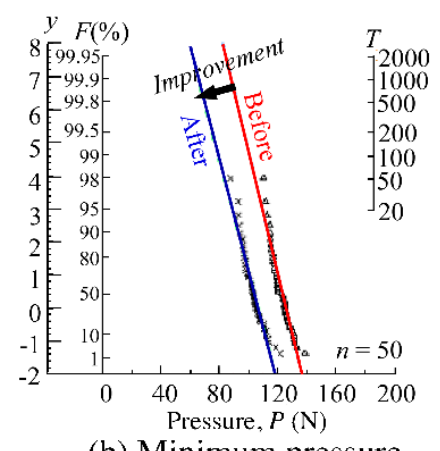

(b) Minimum pressure

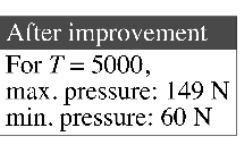

max. pressure: $149 \mathrm{~N}$
min. pressure: $60 \mathrm{~N}$

Fig. 14 Improvement of press load $P$ by changing ceramic component processing.

このように，統計的にばらつきを示す面圧を極值統計の観点から評価することにより製造条件の変更の方向を 正しく決めることができる.この事例は疲労破壊などの部品の破損ではないが，統計的評価の観点からは本質的 に同じ内容を持っており, 同じ手法が他の同様な大量生産部品にも応用可能であることが理解できる. ここで, 注目すべきことは, 個々の部品間の界面の性状や接触状態は部品寸法などの主要パラメータに関する正規分布特 
性には現れないことである．個々の構成部品の寸法などのばらつきが正規分布であっても，組みつけた後の製 品の機能のばらつきが極值統計分布を示寸理由については今後理論的な研究が必要である.

\section{4. 極值統計法を適用するための基本的考え方と指針}

\section{$4 \cdot 1$ 何をパラメータと考えるべきか}

前章までに極值統計法の基本的考え方といくつかの事例について述べた．数 ppm あるいはそれ以下のオーダ の不具合に対応するためには，すでにシックスシグマ（6б）というマネジメント手法があると考えるかもしれ ない. しかし，その方法では，耐久試験での強度の分布や寿命の分布を正規分布と仮定して表現し，製品のばら つきが目標範囲内に入るように設計を行うことになる，その場合，耐久試験の数は限られるので，正規分布での 表現がどれほど正確に分布の裙野の性質を捉えているかは疑問である．また，重要なことは，その正規分布のパ ラメータは不具合を起こす元の原因そのものの定量的データではないことである．例えば，製品を構成する材料 中の介在物や鋳造欠陥が破壊の原因の場合，介在物そのものの統計的性質ではなく，製品の強度または寿命をパ ラメータとしていることである.

\section{$4 \cdot 2$ ストレス・ストレングスモデルの再考}

世界の自動車メーカの技術者によるシンポジウムなどでの講演では，図 15 のようなストレス・ストレングス モデルを使った強度設計の説明が当然のようになされる．このモデルでは負荷応力と部品の強度が正規分布であ ることが仮定されている．この仮定は正しいであろうか? 部品の強度の分布が正規分布であることを確認できる ほど数多くの試験がなされているであろうか? 部品の代わりに疲労試験片を考えてみよう．疲労試験片の破壊は 試験部の最弱部で起こる.1つの試験片の試験部を一定厚さに輪切りした小試験片の集合と考えれば（図 16， 破壊はこの集合の中の最弱の小試験片で起こる．1つの集合（母集団）の各小試験片の強度が正規分布に従うと すると， $N$ 個の試験片すなわち $N$ 個の集合の破壊強度の代表值（最弱值）は正規分布ではなく, 極值分布に従 うことになる(Freudenthal and Gumbel, 1956). このように，現在自動車メーカなどで当然のこととして設計の基 本概念となっているストレス・ストレングスモデルについては部品ごとに根本から考え直す必要がある. 特に, 製品の使われ方が厳しくなっている部品から検討を始めるのが有効であろう.

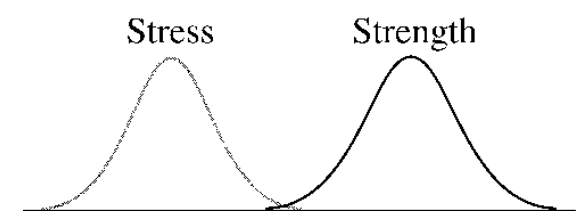

Fig. 15 Stress-Strength model.

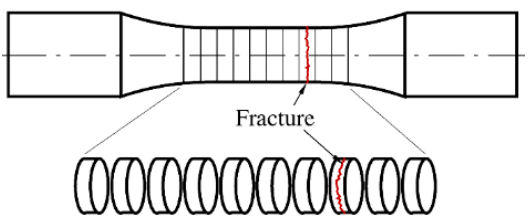

Fig. 16 Fatigue failure at the weakest section. One smooth specimen can be assumed as a set of many small disk specimens.

\section{$4 \cdot 3$ 他の未然防止法との組み合わせ}

本論文で紹介した極值統計法では，製品を過大負荷で壊すことによって計画的に不具合の源を見つけ，それを 定量化する. 不具合の候補となる欠陥などは無数に存在するが，それらの中での極值を取り出すことによって， 市場で起こることが想定されることを未然に防止する. 水素が関与する疲労強度問題などは従来の設計法の枠に は収まらないので，事例 3 のような新たな取り扱いが必要である. ロバストな設計手法として知られているタグ チメソッド（田口, 1988）やさらに総合的な未然防止法として提案された $\mathrm{GD}^{3}$ 法（吉村, 2002, 2011）にここで提 案する方法を組み入れることで数 ppm あるいはそれ以下のオーダの不具合に対してより定量的に対処できるも のと考える. タグチメソッドによれば影響因子を動かすことで系のロバスト性の最適化を行うことができるが， それでもなお影響因子と系全体としての極值統計的性質を見出すことは困難である. これについて, 吉村（吉 村, 2011）は，「タグチメソッドはエネルギーのようなスカラー量で表される問題は得意だが，べクトルの問題 や，組織敏感な問題（局部の形に強く影響される問題）は不得手だと理解した.」と述べている. 吉村はストレ ス・ストレングスモデルが果たしてきた役割を評価しながらも，平均值や分散の推定が少し狂うと大きな問題が 
生じるなど，本論文の要点に関係する問題点も指摘している．この観点からは，GD3 法は Good Discussion とい うプロセスがあるので，新しい発見を手法に取り入れながら柔軟に進化させていく性格を有している.

\section{$4 \cdot 4$ 少量大型生産品などへの応用}

ここで提案する方法は，大量生産品に限らず，少量大型生産品の開発にも応用可能である．もちろん大型少量 製品では, 生産量が少ないので数 ppm オーダの不具合は問題にはならない. しかし, タービンローター, 圧延 ロール，舶用大型歯車などで，事例 3 で説明したような介在物が原因の疲労破壊が危惧される場合には，大型化 するほど危険部位の体積が増大し, 統計的には事例 1 3 で説明したような小寸法製品の大量生産の問題と本質 的に同じ内容を持つことが理解できる. 結果として, 大型機械が 1 機破壊寸るか $10^{6}$ 個の製品の中の 1 個が破壞 するかの違いである. 大型機械の設計では, 歴史的に大容量化に伴って構造の大型化が進められてきた. 一般 に，大型化の際の安全率は同型で小容量の前モデルのものが採用される，その際には，本論文で紹介したような 危険体積の増大を考慮した極值統計的観点の必要性は認識されず，多くの重大事故をもたらしてきた．一つの企 業の得意製品には各企業内で歴史的に築かれ，伝承された安全率がある。しかし，その安全率はそれまでの寸法 の製品には機能していたということだけである．企業で伝承された根抛が曖昧な安全率を使い続けるという発想 は一種の思考停止である.

トライボロジー問題やその他の環境問題に由来する不具合に対しても，ここで提案した極值統計法の基本を応 用することが可能である，その場合にも，過大負荷試験によって原因となる因子の極值を取り出し，定量的評価 に持っていくことが重要である. 設計部門が想定した市場の負荷での限られた数の試験では極值を取り出すこと ができないからである.

近年，本論文で紹介した極值統計手法を導入した実例も国内外で見られるようになったが，企業機密にも関係 しているので, 残念ながら本論文の段階では詳細を紹介できない. しかし，基本的手法は前章で紹介した事例と 同じであり，応用方法は理解できるものと考える.

\section{5. 結言}

極值統計法を大量生産部品の品質管理に適用し, 市場で起こる数 ppm あるいはそれ以下の不具合によって生 じる全製品のリコールを製品開発の初期段階からいかに防止するかの方法を提案し，実践的手法を示した．結論 は次のようにまとめられる.

1. 多くの不具合は製品の疲労破壊などが原因になっている．極值統計法は，これまで $\sqrt{\text { area }}$ パラメータモデ ル（文献および付録参照）と組み合わせて微小欠陥を有する材料の疲労強度のばらつきや強度の下限值などの評 価に有効な実績を示してきた，本論文では，その方法を部品の強度の視点から見た不具合を防止する品質管理に 応用する方法を示した．関連する事例で具体的方法を説明した．

2. 提案した品質管理手法は, 大量生産製品に限らず, 原理的に少量生産の大型機械の不具合または事故防止 にも応用可能である.

3. 提案した方法は，基本的には他の種々の使用形態の動作パラメータから見た機能評価や材料選択の指標に も利用できる．関連する事例で具体的方法を説明した.

4. トライボロジ一問題やその他の環境問題に由来する不具合に対しても, 提案した極值統計法の基本を応用 することが可能である. その場合にも, 過大負荷試験によって原因となる因子の極值を取り出し, 定量的評価に 持っていくことが重要である．設計部門が想定した市場の負荷での限られた数の試験では極值を取り出すことは できない.

5．従来の品質管理法では，極めてまれに起こる疲労破壊などは設計段階では把握しにくく，市場で起こる ppm オーダの不具合の原因を定量的に把握することなく根抛が曖昧な安全率で補うという方法が採用される. そのような方法で不具合が起こらなければ，一応その製品の設計は成功といえるかもしれないが，その製品で採 用した安全率の裹に市場で不具合を起こす可能性のある原因が隠される危険性がある.

6. 現在世界の自動車メーカなどで当然のこととして設計の基本概念となっているストレス・ストレングスモ デルについては根本から考え直す必要がある. モデルの基本となっているストレングスの分布が必ずしも正規分 布ではないからである。 
7. 市場で起こる数 ppm 程度の不具合は設計技術者だけでは避けることができない. 製品開発に関わる異な る企業の技術者間での情報交換による現象理解の共有と極值統計データに基づいた開発変更へのフィードバック が必要である.

\section{付録 1. 疲労強度評価のための $\sqrt{\text { area }}$ パラメータモデル}

リコールの原因となる代表的な材料欠陥である鋳造欠皕や非金属介在物を有する材料の疲労強度は次式で予測 できる（村上, 1993, Murakami and Endo,1994, Murakami, 2002）.

表面欠陥 :

$$
\sigma_{\mathrm{w}}=1.43(H V+120) /(\sqrt{\text { area }})^{1 / 6}
$$

内部欠陥 :

$$
\sigma_{\mathrm{w}}=1.56(H V+120) /(\sqrt{\text { area }})^{1 / 6}
$$

ここで, 各量の定義と単位は, $\sigma_{\mathrm{w}}$ : 疲労限度 $(\mathrm{MPa}), H V$ :ビッカース硬さ $\left(\mathrm{kgf} / \mathrm{mm}^{2}\right), \sqrt{\text { area }}$ ：欠陥を主応力作 用方向に投影した面積の平方根 $(\mu \mathrm{m})(\sqrt{\text { area }}<1000 \mu \mathrm{m})$.

ただし， $\sqrt{\text { area }}$ が極めて小さく，上式で計算した $\sigma_{\mathrm{w}}$ が欠陥の影響のない平滑試験片の疲労限度 $\sigma_{\mathrm{w} 0}\left(\sigma_{\mathrm{w} 0}\right.$ = 1.6HV)を超える場合には，そのような欠陥は疲労限度に悪影響を及ぼさないと考えてよい.

\section{付録 2. 高い応力が作用する危険体積の定義について}

本文中で，”ここで体積とは高い応力が作用し，破壊起点となることが予想される部位の体積（危険体積）で あり, 部品の全体積ではない，総体積とは，1部品の危険部位の体積に生産部品数を乗じた体積である.”と述 べたが，これについて以下のように説明を補足する.

高い応力とは破壊起点の可能性がある部位に作用寸る応力のことであり，応力集中などで応力の勾配がある場 合でも， 1 点の応力を意味するものではない. FEM などで解析すれば, どの部位が高い応力が作用する部位で あるかは予測できる，そのような部位の中で，仮に，ある応力以上が作用する部分を部品 1 個の危険体積と定義 する. ppm オーダの不具合を起こさないために部品 1 個の危険体積に生産個数を乗じた量を総体積 $V_{\mathrm{T}}$ と定義す る. 極值統計線図のデータの基になった試験片の体積（または部品 1 個の危険体積）を $V_{0}$ とすると，再帰期間 $T=V_{\mathrm{T}} / V_{0}$ から可能性のある最大の欠陥寸法 $\sqrt{\text { area }}$ max を推定できる. その欠陥寸法を $\sqrt{\text { area }}$ パラメータモデルの式 に代入すると疲労限度のばらつきの下限值 $\sigma_{\mathrm{wl}}$ が決まる.このようにして， $\sigma_{\mathrm{wl}}$ が ppm オーダの不具合を起こさ ないため最初に高い忍力の部位として仮定した領域内で許容できる応力となる.

高い応力が作用する部位の危険体積としては, 平滑試験片の引張り圧縮疲労の場合には, 単純に試験片平行部 の体積とすればよいが，平滑材でも負荷が曲げやねじりの場合には応力勾配の影響を考慮する必要がある.ま た，砂時計型試験片の引張り圧縮についても断面の応力が一定ではないので，同様な考慮が必要である

(Murakami, 2002)。これまでの多くの実験結果を総合的に考慮すると公称応力の分布から定義して最大応力の 90\%程度の深さまでを危険体積にとることを目安にすることを推奨する. この定義によれば，寸法が 2 倍になれ ば危険体積は 8 倍になる．応力集中があり応力分布が一定でない場合でも最大応力の $90 \%$ か 80\%程度の位置まで の体積を危険体積と見積もればよい． $90 \%$ と 80\%の場合の危険体積の違い，すなわち再帰期間 $T$ の違いは高々 2 倍程度であり, 極值統計線図から求める最大欠陥寸法 $\sqrt{\operatorname{area}_{\text {max }}}$ の值は大差ないので, これによる $\sigma_{\mathrm{wl}}$ の予測值には ほとんど影響がない．それよりも生産部品数が 100 個であるか 1000 個であるか $10^{6}$ 個であるかが再帰期間 $T に$ 桁違いの大きな影響を及ぼすことを重要視しなければならない.

切欠き底に微小な欠陥が存在する場合には，切欠きによる応力分布を考慮して $\sqrt{\text { area }}$ パラメータモデルを適用 する必要がある．切欠き底のごく近傍の応力を第 1 近似として直線で近似し， 欠陥部分での応力を一定応力部分 と直線的に変化寸る応力部分に分けて考える. そして，それぞれの応力分布に対する応力拡大係数を計算し，和 
を求めて, 次式の応力拡大係数で表現される $\sqrt{\text { area }}$ パラメータモデルで微小き裂の疲労き裂進展下限界值 $\Delta K_{\mathrm{th}} に$ 等しくなる公称応力で疲労限度を決定する.

$$
\Delta K_{\mathrm{th}}=3.3 \times 10^{-3}(H V+120)(\sqrt{\text { area }})^{1 / 3}
$$

この方法の具体的手法の説明については文献（Åman et al., 2017）にゆずる.

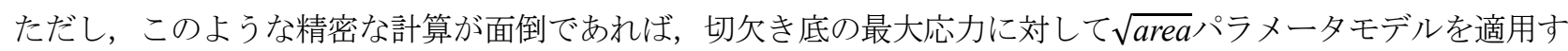
ればよいが，応力集中係数 $K_{\mathrm{t}}$ が高い場合には過度に安全側の評価になる．なぜならば，切久き底と同じ応力が 部品全体に分布していると仮定することになるからである. 次善の方法としては, 切久き底の最大応力と切欠き 半径の 0.1 倍程度内部の応力の平均を採用して, 危険体積を見積もり, $\sqrt{\text { area }}$ パラメータモデルを適用すればよ い. この方法により, 部品の寸法効果も第 1 近似的に考慮される. それが上記引用文献の手法の粗い近似であ る.

なお，特に大きな応力の集中がない場合でも，接触応力と曲げ応力などが重畳する場合には，部品の内部の応

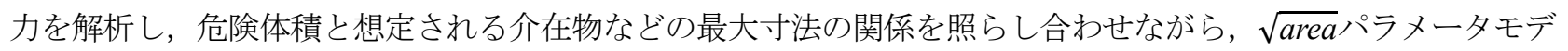
ルで許容応力を決定することができる．その事例が本文の事例 3 である.

いずれの場合にも，総危険体積 $V_{\mathrm{T}}$ と疲労試験片の体積 $V_{0}$ との比から $\sqrt{\text { are }}_{\max }$ を極值統計線図から推定するこ とになる．推定においては，再帰期間 $T$ が大きいほど予測精度が落ちるから基準となる極值データはできるだけ 寸法の大きい試験片で取得することが望ましい，例えば，危険体積の観点からは，直径 $3 \mathrm{~mm}$ の回転曲げ試験片 データは 300 本の試験で直径 $7 \mathrm{~mm}$ の引張り圧縮試験片 1 本のデータにしか相当しない.

このようにして, 部品の生産個数に応じた疲労限度の下限值が決まると, 少なくとも欠陥や介在物が原因と る疲労破壞に対しては，安全率はほぼ 1.0 に近い值をとることができる. 従来の疲労設計法による一定值の安全 率では部品の数や寸法が大きくなるほど余裕度が下がることが考慮されていないのである．従来の安全率もある 部品数までは機能寸るが, 部品数が増えると余裕度はなくなるのである. もちろん, 変動応力など上記の極值統 計問題以外の因子に対する安全率は別に考慮することが必要であることはいうまでもない，なお，紙数の制限で 本論文の範囲では取り扱えなかったが，自動車部品などの変動応力による疲労も基本的には微小き裂の問題であ り，本論文の考え方の拡張（Yamashita and Murakami, 2016)による解決も可能であろう.

\section{文献}

Åman, M., Tanaka, Y., Murakami, Y., Remes, H. and Marquis, G., Fatigue strength evaluation of small defect at stress concentration, to be published in Proc. 3rd International Symposium on Fatigue Design and Material Defects, FDMD 2017, 19-22 September (2017), Lecco, Italy.

淺野間奨，田中章太郎，清水 恭，高城壽雄，（株）タカギ技術資料（2017）.

ASTM E2283-08: Standard practice for extreme value analysis of nonmetallic inclusions in steel and other microstructural features, ASTM Standard (2002).

消費者庁，ニチガス「卓上コンロ用カセットボンベ」（2011 年 12 月～2017 年 1 月製）－返金/回収， $<$ www.recall.go.jp/new/detail.php?rcl=00000017124>（参照日 2017 年 4 月 1 日）.

Fujita, S. and Murakami, Y., A new nonmetallic inclusion rating method by positive use of hydrogen embrittlement, Metallurgical and Materials Transaction A, Vol. A (2013), pp.303-322.

Furuya, Y., Matsuoka, S. and Abe T., A novel inclusion inspection method employing 20KHz fatigue testing, Metallurgical and Materials Transaction A, Vol.34, No.11 (2003), pp.2517-2526.

Freudenthal, A. F. and Gumbel, E.J., Physical and statistical aspect of fatigue, Advances in Applied Mechanics, Vol. IV, H.L.

Dryden and T. Karman. Eds. Academic Press. New York, NN. (1956), pp.117-158.

Gumbel, E.J., Statistics of extremes, Columbia University Press, New York (1958). 日本語訳版, 極值統計学, 河田龍夫, 岩井重久, 加瀬滋男 訳, 廣川書店 (1963).

小林幹和，疲労強度に及ぼすショットピーニングと表面処理の影響，九州大学学位論文（1995）。 
Machida, H. and Abe, T., Fatigue life analysis of a traction drive CVT, Proceedings of international conference of CVT, Yokohama, Japan (1996).

Machida, H., Technology of a traction drive CVT (past, present and future), Proceedings of Leeds-Lyon symposium on Tribology, Lyon, France (2005).

Matsunaga, H., Sun, C., Hong, Y. and Murakami, Y., Dominant factors for very high cycle fatigue of high strength steel and design method for components, Fatigue \& Fracture of Engineering Materials \& Structures, Vol.38, Issue 11 (2015), pp.1274-1284.

Murakami, Y., Metal Fatigue: Effects of small defects and nonmetallic inclusions, Elsevier (2002).

村上敬宜，金属疲労：微小欠陥と介在物の影響，養賢堂（1993）.

Murakami, Y. and Endo, M., Effects of defects, inclusions and inhomogeneities on fatigue strength, International Journal of Fatigue, Vol.16 (1994), pp.163-182.

村上敬宜，川上勝巳，斉藤 誠，自動車ばね鋼の疲労強度に及ぼす介在物の影響，ばね論文集，No.35(1990), pp.17.

村上敬宜，小林幹和，牧野泰三，鳥山寿之，栗原義昭，高崎惣一，江原隆一郎，ばね鋼の疲労強度に影響を及ぼ す諸因子の定量的評価（介在物，ショットピーニング，脱炭層，微小表面ピットの影響)，日本機械学会論文 集 A, Vol.57, No.542 (1991), pp.2305-2313.

Murakami, Y., Nomoto, T., Ueda, T. and Murakami, Y., On the mechanisms of fatigue failure in the superlong life regime ( $>10^{7}$ cycles), Part I: Influence of hydrogen trapped by inclusions, Fatigue \& Fracture of Engineering Materials \& Structures, Vol.23, No.11 (2000), pp.893-902.

Murakami, Y., Nomoto, T., Ueda, T. and Murakami, Y., On the mechanisms of fatigue failure in the superlong life regime ( $\mathrm{N}>10^{7}$ cycles), Part II: A fractographic investigation, Fatigue \& Fracture of Engineering Materials \& Structures, Vol.23, No.11 (2000), pp.903-910.

Murakami, Y., Material defects as the basis of fatigue design, International Journal of Fatigue, Vol.41 (2012), pp.2-10.

NANER，どこまで増えるタカタ製エアバッグのリコール，<https://matome.naver.jp/odai/2140430384133725101> (参 照日 2017 年 4 月 1 日).

田口立一，開発・設計段階の品質工学，品質工学講座 1, 日本規格協会 (1988).

高橋倫也, 志村隆彰, 極值統計学, ISM シリーズ : 進化する統計数理 5, 統計数理研究所編, 近代科学社 (2016).

Roiko, A. and Murakami, Y., A design approach for components in ultralong life with step loading, International Journal of Fatigue, Vol.41 (2012), pp.141-149.

斉藤 誠，伊藤幸生，超清浄鋼の特性について，ばね論文集，No.30 (1985), pp.11-19.

山田耕二，宮川 進，吉川 澄，アルミ合金ダイカストの疲労強度に及ぼす鋳造欠陥の影響，デンソーテクニカ ルレビュー, Vol.7, No.2 (2002), pp.76-82.

Yamashita, Y. and Murakami, Y., Small crack growth model from low to very high cycle fatigue regime for internal fatigue failure of high strength steel, International Journal of Fatigue, 93 (2016), pp.406-414.

吉村達彦，トヨ夕式未然防止法・ $\mathrm{DG}^{3}$ ， 日科技連出版社 (2002).

吉村達彦，想定外を想定する未然防止手法・DG $\mathrm{DG}^{3}$ ，日科技連出版社（2011）.

\section{References}

Åman, M., Tanaka, Y., Murakami, Y., Remes, H. and Marquis, G., Fatigue strength evaluation of small defect at stress concentration, to be published in Proc. 3rd International Symposium on Fatigue Design and Material Defects, FDMD 2017, 19-22 September (2017), Lecco, Italy.

Asanoma, S., Tanaka, S., Shimizu, Y. and Takagi, T., Technical Report, Takagi, Co. Ltd. (2017) (in Japanese).

ASTM E2283-08: Standard practice for extreme value analysis of nonmetallic inclusions in steel and other microstructural features, ASTM Standard (2002).

Consumer Affairs Agency, Nichi-Gas portable gas cassette container, <www.recall.go.jp/new/detail.php?rcl=00000017124> (accessed on 1 April, 2017). 
Fujita, S. and Murakami, Y., A new nonmetallic inclusion rating method by positive use of hydrogen embrittlement, Metallurgical and Materials Transaction A, Vol. A (2013), pp.303-322.

Furuya, Y., Matsuoka, S. and Abe T., A novel inclusion inspection method employing 20KHz fatigue testing, Metallurgical and Materials Transaction A, Vol.34, No.11 (2003), pp.2517-2526.

Freudenthal, A.F. and Gumbel, E.J., Physical and statistical aspect of fatigue, Advances in Applied Mechanics, Vol. IV, H.L. Dryden and T. Karman. Eds. Academic Press. New York, NN. (1956), pp.117-158.

Gumbel, E.J., STATISTICS of EXTREMES, Columbia University Press, New York (1958).

Kobayashi, M., Effects of shot peening and surface treatment on fatigue strength, PhD Dissertation, Kyushu University (1995).

Machida, H. and Abe, T., Fatigue life analysis of a traction drive CVT, Proceedings of international conference of CVT, Yokohama, Japan (1996).

Machida, H., Technology of a traction drive CVT (past, present and future), Proceedings of Leeds-Lyon symposium on Tribology, Lyon, France (2005).

Matsunaga, H., Sun, C., Hong, Y. and Murakami, Y., Dominant factors for very high cycle fatigue of high strength steel and design method for components, Fatigue \& Fracture of Engineering Materials \& Structures, Vol.38, Issue 11 (2015), pp.1274-1284.

Murakami, Y., Metal Fatigue: Effects of small defects and nonmetallic inclusions, Elsevier (2002).

Murakami, Y., Metal Fatigue: Effects of small defects and nonmetallic inclusions, Yokendo, Tokyo (1993) (in Japanese).

Murakami, Y. and Endo, M., Effects of defects, inclusions and inhomogeneities on fatigue strength, International Journal of Fatigue, Vol.16 (1994), pp.163-182.

Murakami, Y., Kawakami, K. and Saito, M., Effects of inclusions on fatigue strength of a suspension spring steel, Transaction of Japan Society of Spring Res., No.35 (1990), pp.1-7.

Murakami, Y., Kobayashi, M., Makino, T., Toriyama, T., Kurihara, Y., Takasaki, S. and Ebara, R., Quantitative evaluation of the factors influencing fatigue strength of spring steels (Effects of nonmetallic inclusions, shot peening, decarburized layer and small surface pits), Transaction of the Japan Society of Mechanical Engineers, Series A, Vol.57, No.542 (1991), pp.2305-2313.

Murakami, Y., Nomoto, T., Ueda, T. and Murakami, Y., On the mechanisms of fatigue failure in the superlong life regime $\left(\mathrm{N}>10^{7}\right.$ cycles), Part I: Influence of hydrogen trapped by inclusions, Fatigue \& Fracture of Engineering Materials \& Structures, Vol.23, No.11 (2000), pp.893-902.

Murakami, Y., Nomoto, T., Ueda, T. and Murakami, Y., On the mechanisms of fatigue failure in the superlong life regime ( $>10^{7}$ cycles), Part II: A fractographic investigation, Fatigue \& Fracture of Engineering Materials \& Structures, Vol.23, No.11 (2000), pp.903-910.

Murakami, Y., Material defects as the basis of fatigue design, International Journal of Fatigue, Vol.41 (2012), pp.2-10.

NANER, Where is the upper limit of recall of Takata airbag?, <https://matome.naver.jp/odai/2140430384133725101> (accessed on 1 April, 2017).

Taguchi, G., Kaihatsu sekkei dankai no hinshitu kogaku, Hinshitu Kogaku Koza 1, Nihon Kikaku Kyokai (1988) (in Japanese).

Takahashi, R. and Shimura, T., Kyokuchi tokei gaku, ISMSeries: Sinka suru Tokei Suuri 5, Ed. Tokei Suuri Kenkyusho, Kindai Kagaku sha (2016) (in Japanese).

Roiko, A. and Murakami, Y., A design approach for components in ultralong life with step loading, International Journal of Fatigue, Vol.41 (2012), pp.141-149.

Saito, M. and Ito, Y., Some properties of ultra clean spring steel, Trans. Japan Soc. Spring Res., No.30 (1985), pp.11-19 (in Japanese).

Yamada, K., Miyakawa, S. and Yoshikawa, S., DENSO Technical Review, Vol.7, No.2 (2002), pp.76-82 (in Japanese).

Yamashita, Y. and Murakami, Y., Small crack growth model from low to very high cycle fatigue regime for internal fatigue failure of high strength steel, International Journal of Fatigue, 93 (2016), pp.406-414.

Yoshimura, T., TOYOTA-shiki mizenboshi-ho $\cdot \mathrm{DG}^{3}$, Nikka Giren Shuppansha (2002) (in Japanese).

Yoshimura, T., Expect exception mizenboshi method, Nikka Giren Shuppansha (2011) (in Japanese). 